\title{
Management of Wild Ungulate Habitat in the Western United States and Canada: A Review
}

\author{
GEORGE W. SCOTTER
}

\section{Abstract}

Conservation, use, and development of adequate habitat are probably the most important factors in wild ungulate management. As the various demands on the habitat heighten, pressure on this dwindling resource will increase. To maintain viable wild ungulate populations with high sustainable yields for the future enjoyment and use, habitat management will have to be intensified. This review discusses rehabilitation of wild ungulate habitat, modification of range and forest practices, better use of existing habitat, and manipulation of numbers and distributions of wild ungulates. The amounts and kinds of habitat needed to maintain wild ungulate populations require more long-term research and better application of existing knowledge. Determination of the requirements for a given species will demand a much better understanding of how animals select and use habitat.

Leopold (1933) defined game management as “ . . .the art of making land produce sustained annual crops of wild game for recrcational use.' One facet of the art involves management of habitat to increase or better support numbers of desired animals. Direct manipulation of populations also may be applied, either to increase or decrease numbers of animals depending upon the state of balance between the animals and their habitats. Management of habitats and of populations are closely linked.

Conflicts among resource managers will become more acute and difficult to resolve over the next few decades. Wildland will be withdrawn from use as wild ungulate habitat by highways, strip mines, water development projects, urban expansion, second home development, and pipelines. Other land uses, such as farming, some types of ranching, timber production, and watershed management may be competitive in varying degrees.

Concurrently, man's interest in sport hunting and recreation will greatly increase demands for animals. It has been projected that by the year 2000, participation in sport hunting will increase about $80 \%$ from the 1960 level (Outdoor Recreation Resources Review Commission 1962). Even greater increases are predicted for other recreational activities in which wild ungulates are a major attraction, such as hiking, driving, photography, and nature studies (Forest-Range Task Force 1972).

Improved fire protection has contributed to the loss of habitat by permitting succession to plant communities with low capacity to support some ungulates. During the early 20 th century and before, wildfires regularly burned large areas of the western United States and Canada. Much of the post-fire vegetation provided favorable forage for certain game species, especially deer (Odocoileus spp.) and elk (Cervus elaphus), whose numbers subsequently increased (Lyon 1966a). Im-

Author is Chief, Wildlife Research and Interpretation Division, Canadian Wildlife Service, Western and Northern Region, Room 1000, 9942108 Street, Edmonton, Alberta, T5K 2J5. Manuscript received December 1, 1977.

A number of people in the range and wildlife professions provided critical comment and stimulating debate on drafts of this paper. Chief among those were R.A. Demarchi, R.M. Hansen, D. Hocking, R.J. Hudson, L.J. Lyon, F.L. Miller, S. Smoliak, and I. Stirling. To them and the others who supplied comments and data, the author expresses his thanks. proved fire protection in recent years has allowed more areas to develop climax forests having lower carrying capacities for some species of wild ungulates. For instance, in Region One of the U.S. Forest Service, which includes Idaho, Montana, and Washington, the area burned by wildfire declined from an annual average of 101,000 ha $(250,000$ acres $)$ at the turn of the century to less than 2,000 ha $(5,000$ acres) in the early 1960 's (Pengelly 1966). As a result, many of the former repeatedly burned-over areas that were maintained as grassy and shrubby stands are now reverting to forests. These patterns of succession are reducing the quality and extent of ungulate habitats and consequently, the numbers of wild ungulates.

As an outcome of these developments, the questions confronting game managers are: Can the quality of wild ungulate habitat be improved, or its quantity increased, to provide recreational hunters and others with resources similar in level and quality to those which they generally enjoyed? Or, in the face of expanding human populations and demands for resources, must the game manager expect only to minimize the losses?

We have already lost too much good habitat and we should strive to minimize future losses and recover that already lost. Realistically, given other demands, the major future objective of managers will be to maintain viable populations with high sustainable yields on smaller areas.

Major habitat management programs require definition of objectives, which demands examination of values because certain objectives may be incompatible. For example, although habitat management programs may bring about gains in wild ungulate production, such programs also may reduce the subjectively perceived "naturalness" of the landscape and consequently the quality of the recreational experience. In some areas, the most advanced management concept may be to let habitats and populations find a dynamic natural equilibrium. The concept of "two deer in every pot" as a universal objective of game management should be questioned.

This paper will be limited mostly to wild ungulate habitats within the western states and provinces of the United States and Canada. Approximately $80 \%$ of this area is forest and rangeland of prime importance as habitat for wild ungulates. The region contains biotic zones ranging from alpine tundra to hot deserts with large areas under agricultural use. Several major grass, shrub, grass-shrub, and forest vegetation types occur. Each of these plant communities has a different potential for supporting wild ungulates.

Many wild ungulates use different ranges seasonally. Generally, it is the size, productivity, and availability of the winter range that limit the numbers of these ungulates. Exceptions to this rule include the plateau area of southeastern Utah, where there is a limited summer range but ample winter range, and the lower-desert type habitats in Nevada, Arizona, and New Mexico, where the winter range is larger than the mountain areas occupied during the summer. The rule is well illustrated in the northern portion of the western Cordilleran 
region, where the winter range for deer, moose (Alces alces), bighorn sheep (Ovis canadensis), elk, and, to some extent, for caribou (Rangifer tarandus), and mountain goats (Oreamnos (americanus) is small compared to the spring-summer-fall range (Stelfox and Taber 1969). The size of winter range in the northern area varies according to snow cover; the areas used in winters with light snow cover are several times the sizes of areas used in winters of heavy snow cover. Topographical features such as slope, exposure, aspect, and elevation also influence, singly and in combination, the extent of winter ranges.

In some cases, wild ungulates are on sub-maintenance diets during the winter; the physical conditions of such ungulates when they return from summer and fall ranges, therefore, can influence their winter survival. Because well-nourished wild ungulates can survive body-weight losses over the winter period, the quality of diet provided by their summer ranges may be critical.

In the past, the habitats of some wild ungulates were often improved by wildfire, logging, abandonment of improvidently located croplands, and overgrazing by domestic stock. Today's game managers cannot rely on such factors to fortuitously create or improve habitat. Creation or enhancement of habitat in the future must be planned and coordinated with other uses. Methods of improvement, development, and maintenance of habitats for wild ungulates in western forests and on rangelands may be categorized as follows: (1) rehabilitation practices with the sole or primary objective of habitat improvement, (2) modification of other forest and range practices, (3) enhancement of existing wild ungulate habitat, and (4) manipulation of the numbers and distributions of wild ungulates to prevent destruction of their habitats.

\section{Rehabilitation Practices Primarily for Improvement of Wild Ungulate Habitat}

In many areas of the western United States and Canada, ranges have been severely depleted because of repeated overuse by wild ungulates and domestic stock. Such depleted ranges can be rehabilitated or improved, despite environments which are inimical for plant establishment. The choice of methods would depend on the nature and extent to which such ranges have been depleted, on the planned use, and on the climatic, edaphic, and topographic features of the particular area.

However, rehabilitation is a curative measure and not a substitute for continued good management of habitat and wild ungulates. There are two main reasons why management must be sustained. Firstly, where rehabilitation involves seeding and planting, the manager most often uses cultivated or exotic plant varieties because seeds of native plants are of limited availability. Introduction of exotics often disrupts and displaces the natural plant communities, and the resulting instability requires monitoring for further management action. Secondly, range improvements generally result in increased production and survival of some wild ungulates; these increases could be followed by overgrazing to an extent that would outstrip production of forage. Without improved management of habitat and ungulates, the carrying capacity of the habitat would then be reduced again.

Most techniques are aimed at producing more forage, an objective based on the premise that forage is the habitat factor that limits wild ungulates. This premise has not been critically examined; other habitat components, such as type and amount of cover, may be equally important.

\section{eeding and Planting}

Methods and equipment have been developed to facilitate the process of range restoration through seeding or planting of mixtures of shrubs, forbs, and grasses (Plummer 1958; Holmgren and Basile 1959; Hubbard 1962, 1964; Plummer at al. 1968; Medin and Ferguson 1972; Stevens et al. 1974).

Sometimes seeding or planting must be preceded by removal of undesired competing species. The dense stands of pinyonjuniper (Pinus spp. and Juniperus spp.) common on wild ungulate winter ranges in Utah, Nevada, Arizona, and New Mexico, are an important habitat component because they provide cover for wildlife, but these species produce very little forage. Fire suppression and reduction of understory fuel through heavy grazing have combined to permit dense stands of these species. To increase production of usable forage, competition first must be reduced through removal of tree cover from portions of overgrown areas (Plummer 1958). Establishment of forage by seeding a browse-forb-grass mixture may still be difficult because the amount and seasonal distribution of precipitation often is unreliable.

Tree removal and seeding are expensive treatments. They can restore forage productivity, but it is questionable whether actual projects have achieved maximum return for wild ungulates because of failures to consider other habitat factors. Projects have frequently applied such treatment to thousands of hectares in one block, although wild ungulates would benefit more from treatment of smaller areas. Terrel and Spillett (1975) recommend that for maximum use by mule deer (Odocoileus hemionus hemionus), openings in pinyon-juniper should be no more than $0.32 \mathrm{~km}(0.2$ mile) in width and that conversion to forage species should be limited to $25 \%$ of the stand in any 25-year period. Minnich (1969) suggested that, in Colorado, deer would benefit most from forage areas chained in blocks or strips but not more than $0.20 \mathrm{~km}(0.125$ mile $)$ from undisturbed cover. Thinning is beneficial for deer but is not recommended because it is only temporary: the shallow, spreading root systems of pinyons and junipers are extremely competitive and reestablish rapidly. Better long-term management demands complete removal, which may be more expensive but longer-lasting.

One approach with potential for improving or developing new wild ungulate habitat on depleted ranges is the selcction and breeding of superior browse and forb plants. Many desirable traits, such as high palatability, high productivity, longevity, drought tolerance, ease of establishment, and disease resistance, may exist in certain ecotypes, offering many opportunities for improvement of these plants.

To obtain the full benefits from such plant selection, research into the life histories and ecological requirements of important native shrubs is required (McKell et al. 1972). For example, the forage quality of fourwing saltbush (Atriplex canescens) can be improved through selective breeding because it hybridizes readily and has a wide range of genetic variation (Plummer et al. 1966). Experimental seedings of highly palatable ecotypes of big sagebrush (Artemisia tridentata) and rabbitbrush (Chrysothamnus sp.) also show promise (Plummer et al. 1968; Hanks et al. 1973, 1975; McArthur et al. 1974). Detailed studies are available for a few other species such as bitterbrush (Purshia tridentata) (Holmgren and Basile 1959; Hubbard 1964; Nord 1965); fourwing saltbush (Plummer et al. 1966; Springfield 1970); blackbrush (Coleognyne ramosissima) (Bowns and West 1976); and sagebrush subspecies (Plummer et al. 1968). Little is known, however, about many other native shrubs. 
The U.S. Forest Service has established a laboratory at Provo, Utah, to develop and improve superior shrubs principally for use by wild ungulates. The laboratory will also test exotic shrubs.

\section{Herbicides}

Certain plant communities can be manipulated through use of herbicides to favor production of desirable browse and forbs and to suppress less desirable plants. Although some promising results have been obtained, the responses of habitats to herbicide treatments are not yet reliably predictable because the product, dosage, time of application, and target species are variable. A few examples of herbicide use on wild ungulate range follow.

In Idaho, herbicide treatments (2,4-D; 2,4,5-T; and a mixture of both) were used as top-kill to increase the basal sprouting of several browse species that had grown beyond the reach of wild ungulates (Mueggler 1966). In a later reexamination, Lyon and Mueggler (1968) found that persistence of sprouting among browse plants was generally poor and that desirable species recovered relatively quickly from crown dieback; however, they also found a loss of the most desirable browse, redstem ceanothus (Ceanothus sanguineus), in all treatments. In Oregon, experimental spraying of low sagebrush (Artemisia arbuscula) on antelope (Antilocapra americana) summer range with 2;4-D butyl ester resulted in a pronounced increase of grasses and forbs; this increase improved that range by reducing competition from low sagebrush (Cook et al. 1968). Chemical control of big sagebrush with 2;4-D ester on important elk ranges in Wyoming resulted in earlier vegetation growth and as high as $89 \%$ more use by elk than untreated areas (Wilbert 1963). In southeastern Oregon, however, big sagebrush ranges that were rehabilitated through spraying with $2 ; 4-\mathrm{D}$ were not more attractive to antelope than untreated ranges (Reeher 1969).

In western Oregon, multi-herbicide (principally atrazine, dalapon, silvex, and 2;4-D) applications to half of each of three Douglas fir (Pseudotsuga menziesii) clearcuts reduced the numbers of grasses and forbs and increased growth of most shrubs and Douglas fir (Borrecco et al. 1972). Treatment of sites resulted in different seasonal patterns of browse use, but the differences in the amount of browsing on Douglas fir by black-tailed deer (Odocoileus hemionus columbianus) were insignificant. Borrecco et al. (1972) concluded that the net result of herbicide application was an improvement in the habitat for black-tailed deer.

Hoffer (1972) reported a 63\% increase in deer use of chamise (Adenostoma fasciculatum) and Lemmon ceanothus (Ceanothus lemmonii) on winter range in northwestern California 2 years after application of 2,4-D. His results indicated that treatment in early October killed the most chamise, which is the least valuable forage, and increased the desirable ceanothus. 2,4,5-TP treatments were applied on oakbrush (Quercus gambelii) in winter ranges in Colorado to determine whether carrying capacity for deer and elk could be increased. Kufeld (1977) reported 73 and $16 \%$ more use of treated areas by elk and deer, respectively, 2 years after spraying; respraying at 3 -year intervals was required to maintain effects.

Indiscriminate application of herbicides can result in a loss of both cover and forage. Moreoever, it is possible that certain herbicides or their impurities could cause abnormalities in some animals (Dost 1973; Shapley 1974). No cases have been documented of lethal effects of herbicides when properly applied. Herbicides should be either plant-specific or effective on a narrow spectrum of plants; also, herbicides should be short-lived or should prevent reinvasion of only the target species; they should break down into harmless by-products and should contain no impurities. The negative effects of herbicides on cover and forage production for wild ungulates, especially when large blocks of habitat are treated, can be more important than the potential threat of abnormalities. However, it is possible that legal restrictions on the widespread use of herbicides will prevent their future application.

\section{Mechanical Treatment}

Mechanical treatments such as chaining, railing, crushing, root piowing, clipping, and pruning can be applied to shrubs to improve production of desirable browse plants. However, the results obtained from such treatments are highly variable and generally temporary.

Variation in results is illustrated by experience with treatments of shrub species. In many Intermountain areas, stands of curl-leaf mountainmahogany (Cerocarpus ledifolius) have grown beyond the reach of wild ungulates. Attempts have been made to rejuvenate some stands in northern Utah by chaining. One year after chaining, good browse potential was developing in an estimated 100,000 mahogany seedlings per ha, but most of the seedlings died during the second summer $(F$. Gunnel, pers. comm.), perhaps because of drought. In other areas of Utah, top pruning of mahogany shrubs almost doubled usable browse production (Thompson 1970). In Wyoming, however, mechanical and chemical rehabilitation of mountainmahogany (Cercocarpus montanus) stands reduced browse production (Diem 1963). Such variable results could be better understood if operational treatments were planned beforehand to include control areas with no treatment or adjusted treatments, and then followed-up with careful evaluation of results. A knowledge of effects of different methods on the forage production of important browse species, applied under different climatic conditions and under different physiological cycles of plant growth, is necessary to enable correct selection of mechanical methods of improving habitat.

Follow-up studies of treatments with significant initial benefits, have indicated the temporary nature of improvements. Clipping the tops of tall bitterbrush plants in southern Idaho increased available twig growth severalfold the year after treatment (Ferguson and Basile 1966; Ferguson 1972). Treated shrubs continued to produce more than the control shrubs during the 3 years subsequent to treatment, but each year the rate of production of the treated shrubs was reduced. Similar studies are needeci on the closely related cliffrose (Cowania stansburiana) and on other important browse species, for large areas exist where most of the browse growth is beyond the reach of wild ungulates.

\section{Prescribed Burning}

Early observations of the beneficial effects of wildfire led to development of prescribed burning as a tool to modify plant succession. It has been found to be a practical and effective means of rejuvenating winter ranges for some wild ungulates, being both relatively inexpensive and long-lasting. For example, on the Kenai National Moose Range in Alaska, favorable browse conditions have persisted for 5 to 20 years, occasionally for 60 to 70 years or more, after wildfire in the boreal forest (Spencer and Hakala 1964). Favorable results have also been obtained from prescribed burning of moose range in Wells Gray Provincial Park, British Columbia (Eastman 1978).

Valuable experience also has been obtained in ranges of the southwest and Intermountain areas. In California and Arizona, 
dense stands of chaparral impede wild ungulate movement and provide little forage. Prescribed burning and mechancial treatments to create openings resulted in a marked increase in production (up to 45 fold), palatability, and nutritive value of deer forage (Sampson 1944; Biswell et al. 1952; Taber 1956; Richards 1957; Taber and Dasmann 1958; and Biswell 1961). Fire is also being using in northern Idaho (Lyon 1966a; Leege 1968, 1969; Leege and Hickey 1971) and on deer winter ranges in California (Biswell and Gilman 1961) in an attempt to increase both browse production and availability. Lyon (1966b, 1971) reported that wildlife habitat was markedly improved through prescribed burning in a Douglas fir forest in south-central Idaho. However, he cautioned that firc is not a panacea and should be used in specific locations only if the results are predictable.

Many land managers are coming to recognize the often positive effects of fire on habitat. Policies that called for protection of low-value timber stands are giving way in some areas to a "let it burn" policy. Fire is now allowed to play its natural role in several national parks and in certain primitive and wilderness areas of western Canada and the United States. This undoubtedly will help to keep such areas in good habitat condition for wild ungulates.

Development of these policies stems from careful documentation of certain detrimental effects of the exclusion of fire, one of which is forest encroachment. Stelfox (1975) reported that forest encroachment on grassland ranges was a significant factor in reducing the carrying capacities of certain national parks of western Canada for Rocky Mountain bighorn sheep (Ovis canadensis canadensis). He identified five eruptive fluctuations of bighorn sheep between 1936 and 1967. Sheep populations increased until winter ranges became overgrazed and concurrently, endoparasite burdens increased. Eventually malnutriton and a pneumonia-lungworm complex decimated high eruptive populations. Range conditions improved after population declines; and, in turn, the sheep populations increased until the cycle was repeated. One suggested solution was to permit some wildfires to run their natural course to maintain or create successional seres with greater carrying capacities, and to reduce population fluctuations of sheep.

Sometimes the land manager cannot wait for wildfire; or a more precise burn is desired. Prescribed burning has recently been applied to winter ranges of Rocky Mountain bighorn sheep and California bighorn sheep (O.c. californiana) in British Columbia (R.A. Demarchi, pers. comm.). Lauer and Peek (1976) have suggested that controlled burning of specific sites where grasses are more prevalent could enhance winter ranges of bighorn sheep on the East Fork of the Salmon River, Idaho.

Many data are available on when and how to burn, on the postfire responses of vegetation, and on the influence of fire on soil properties; recorded in a sequence of reviews and conference proceedings: "The role of fire in the Intermountain West" (Intermountain Fire Research Council 1970); "Fire in the northern environment" (Slaughter et al. 1971); "Fire in the environment" (Forest Service 1972); "The ecological role of fire in natural conifer forests of western and northern America", (Wright and Heinselman 1973); and the annual proceedings of the Tall Timbers Fire Ecology Conference. Among these data are sufficient facts for an experienced range manager to draw conclusions respecting application of prescribed burning to most practical situations.

Improvement of Habitat through Coordination of Primary Uses

Past management of most private and public lands has been argely on a functional basis, with a responsibility for maximizing a single product. With the public land base shrinking and more people demanding more goods and services from a smaller area, comprehensive land-use planning should be employed to ensure an extensive list of benefits. For managers to run an integrated land management program they must be natural ecosystem managers - not just foresters, range scientists, or wildlife specialists. Such an integrated land management program may not maximize output from a single resource, but neither will certain values be suppressed. Over the long term, integrated land management should assure the greatest aggregate output of tangible and intangible benefits and services from public lands. A clear understanding of the public's wants, needs, and demands with regard to the resources from public lands is required for such planning.

Where ownership and control rests with private entities, there may be little or no incentive to participate in an integrated land management program because immediate monetary returns may not be maximized. Landowners may be encouraged to practice better integrated land management with wildlife resources if recreationists could be charged for access to property.

Natural ecosystem managers, by modifying primary activities such as timber management and range improvement for domestic livestock, could help enhance wild ungulate habitat at less cost than if these programs were conducted independently. Tremendous opportunities exist in the sheer scale of operations in logging and range livestock production. When 800,000 ha (2 million acres) of the 97 million ha ( 240 million acres) of forest in the 11 western states are logged annually, and when millions of the 182 million ha ( 450 million acres) grazed by domestic livestock are being rehabilitated, public land managers should not overlook the opportunities provided for improving wild ungulate habitats.

\section{Timber Management Practices}

The forest industry is in a unique position to influence wild ungulate diversity and abundance because of its control over the direction of land-management programs in much of western North America. Logging of forests often induces successional patterns similar to those following wildfire and often improves habitats of wild ungulates. Other timber management practices can sometimes be manipulated to enhance game habitats without seriously hindering the economics of forest management.

Range balance for ungulates should be among the factors considered when the patterns of logging operations are being determined. Range balance seeks to achieve the optimum combination of habitat for food, shelter, and other requirements of an animal species, all within its home range. Determination of the range balance sought by interspersion of habitat types must relate to the mobility of the wild ungulates being managed. Because there is a limit to the distance animals will or can move to meet their habitat requirements, the ways in which logging practices can be adjusted to wild ungulate requirements need to be precisely determined.

A forecast of postlogging successional effects on habitats should be provided by wildlife managers for inclusion in comprehensive land-use planning; such a forecast would enable natural ecosystem managers to make decisions regarding cutting of forests to maximize values for wild ungulates, other wildlife, and other resources. It should be determined, for example, what stages of the post logging vegetational succession produce maximum forage for ungulates. The optimum long-term yield of ungulates from a habitat should also 
be estimated. For example, according to Reynolds (1962), the maximum yield occurred 6 years after logging ponderosa pine (Pinus ponderosa) stands in northern Arizona and populations of deer declined to original levels 15 years after logging. He concluded that logging was beneficial to deer for the first 11 years. Pengelly (1963) reported that forage for ungulates increased for 15 years after logging of Douglas fir-ponderosa pine stands in Montana and Idaho, declining to original levels in 20 to 40 years. But clearcutting and thinning of lodgepole pine $(P$. contorta) regeneration in Montana stimulated forage production for an estimated 20 years or more, and peak production occurred approximately 11 years after clearcutting (Basile and Jensen 1971). Gates (1968) stated that forage for ungulates increased for 6 to 8 years after logging of coastal forests on Vancouver Island and declined over a 100-year period. Following clearcuts in the coniferous forests of western Washington, numbers of black-tailed deer increased for 10 to 15 years (Brown 1961), but the population was higher and maintained its peak longer when natural regeneration failed than when it succeeded.

Edgerton (1972), in northcastern Oregon and southeastern Washington, found use by elk during the five growing seasons following logging was highest in the clearcut and lowest in the partially cut forests; deer showed a similar but a less marked preference for clearcut areas. In contrast, Lyon (1975) reported a continuing decline in numbers of elk pellets in a drainage with logging and road construction compared with adjacent undisturbed drainages in western Montana. In a mixed coniferous forest of northeastern Oregon, logging also increased shrub production and forage potential for wild ungulates (Young et al. 1967).

Logging improved forage abundance for deer in an area of lodgepole pine and spruce-subalpine fir (Picea engelmanniiAbies lasiocarpa) timber in Colorado. Wallmo et al. (1972) reported that 15 years after logging more forage was available and deer spent more of their feeding time in cut strips than in uncut strips of equal size. The preference for logged areas was related to the increased amount and variety of forage available but not to greater crude protein content or digestibility of forage (Regelin et al. 1974).

Stelfox et al. (1976) studied the effects of logging and soil scarification in white spruce (Picea glauca) forests in wildungulate habitat in western Alberta. Areas that were scarified after logging produced less browse than did areas that were logged only. The logged area was used as summer range by deer during the first 5 years, by deer and elk year-long during the sixth year, and by deer, elk, and moose year-long during the seventh through tenth years. After 17 years of regeneration, wild ungulate use was nearly 19 and 65 times greater on scarified and logged strips, respectively, than in the mature forest (Stelfox et al. 1976).

The size and shape of clearcuts and their position in relation to uncut timber are important considerations for improvement of ungulate habitat. Reynolds (1966a, 1966b) found that deer and elk in Arizona made greatest use of logged areas adjacent to uncut timber. Circular openings of approximately 8 ha (20 acres) in spruce-subalpine fir stands and 18 ha (45 acres) in ponderosa pine stands were most beneficial for deer and elk. For well-stocked ponderosa pine stands in Arizona, Patton (1974) recommended that cuts varying in size from a few hectare to 13 ha (32 acres) would benefit deer and elk as long as the cut area is not more than $488 \mathrm{~m}(1,600 \mathrm{ft})$ across. According to Jones (1975), the size of aspen (Populus tremuloides) clearcuts can be as small as 2 ha ( 5 acres) and not be seriously overbrowsed $t$ moderate numbers of deer, elk, and cattle; generally, howeve clearcuts should be larger or there should be a few small plo within the same general area to spread browsing pressure. Telf (1974) pointed out that ". . . it appears that the type of loggir that creates a mosaic of small patches and strips of different aq classes will greatly benefit deer, while larger clear cuts will t harmful because they deprive deer of the cover that they requil for protection against severe snow conditions, wind, an disturbance."

Although habitat diversity is most favorable for moos (Pimlott 1953; Vozeh and Cumming 1960; Bergerud an Manuel 1968; Prescott 1968; LeResche et al. 1974), thes animals will use much larger clearcuts and will tolerate le: shelter than deer. Telfer (1974) suggested that moose could us clearcut areas of 128 ha ( 0.5 square miles). Logging in easter Canada resulted in a greater than 50-fold increase in brows yield 7 years after cutting (Telfer 1970). However, Markgre (1974) reported that large, progressive-type clearcuts, 5 or mot ha ( $>12$ acres) in size, may be of less benefit to moose tha clearcuts of approximately 2 ha ( 5 acres) because of reduce cover and a changing of local climate involving a gradu: drying-up of the soil.

Thinning to improve tree growth can improve understor vegetation for game. Herbaceous vegetation generally dc creases as forests age and canopies close (Cowan et al. 1950 Pase 1958; Reid 1964). In most cases, production of forage $i$ inversely related to the basal area of the remaining tree stand Although in some regions overthinning can further enhanc habitat values, clearcutting in small tracts generally results $i$ greater forage production.

Prescribed burning is frequently used after clearcutting, $t$ dispose of logging slash and encourage natural regeneration o prepare the ground for seeding or planting. Approximatel 40,500 ha (100,000 acres) are burned annually in Region One o the U.S. Forest Service (Pengelly 1966). Future research ma' indicate that this practice can further improve wild ungulat habitat. Reynolds (1966a, 1966b) demonstrated that the sizes o openings and slash clean-up practices do influence wil ungulate use.

The marked increases in forage production resulting fror certain forest management practices encourage use of the area by ungulates. Proper management of both wild ungulates an livestock is therefore essential for regeneration of trees Livestock cause substantial damage to aspen regeneratio: (Sampson 1919; Baker 1925; Smith et al. 1972). Wild ungulate can have the same effect; for example, excessive deer use o: some clearcuts of Douglas fir stands have delayed or eve: prevented reforestation in Oregon, Washington, and Britis Columbia.

To promote dynamic wildlife herds, it is essential to predic the longevity and productivity of habitats resulting from forestr. operations. Such data would also allow managers to maximiz wild ungulate harvests when the habitats are most productive Also, wild ungulate harvests must be adjusted accordingly $t_{t}$ protect both forestry and wildlife interests.

When planning for forestry and wild ungulates, lan managers should recognize that different wild ungulate specie may prefer different specific stages of forest succession. Dee and moose benefit from the immediate to mid-term increase i1 food production that generally follows fire or logging in borea forests (Dodds 1960; Idstrom 1965; Bergerud and Manual 1968 Scotter 1971). In contrast, fire and logging cause a long-tern 
loss of winter habitat for mountain, woodland, and barrenground caribou, which generally prefer more mature forests because of a great abundance of arboreal and terrestrial lichens, important components of the winter diet (Edwards 1954; Simkin 1965; Scotter 1971). In Riding Mountain National Park, Manitoba, elk preferred foraging in burned-over forest to climax forest, and in climax grassland to seral stages resulting from cattle grazing (Blood 1966). The development of young conifer stands following fire in Glacier National Park, Montana, enhanced the habitat carrying capacity for elk (Martinka 1976) by providing food and reducing environmental stress during critical winter periods. Martinka suggested that habitat structure complemented the forage base to provide optimal wintering conditions for elk in those stands. Moose populations in the Jackson Hole region, Wyoming, inceased with advanced successional vegetation because of an increase in sub-alpine fir, which is a staple food item in their diet (Loope and Gruell 1973). Spring burning has been applied to an aspen-conifer stand for maintenance of moose habitat in the West Boulder River region, Montana (Gordon 1976). Aspen and most shrub components of the stand sprouted vigorously from rootstocks following the burn and increased the amount of browse available to moose.

In a study of the cost of modifying forest industry practices to benefit other resources in Alberta, Schultz and Co. Ltd. (1973) found that "special game" areas of up to $20 \%$ of a company's holdings could be managed separately for an additional estimated cost of only 5 cents per cunit ${ }^{1}$ on the total cut. Separate management treatments could include a combination of the following techniques: strip cutting, lengthening the interval between removal of timber in adjacent strips to more than 30 years, partial cutting, or a combination of these techniques. Longer cutting intervals, smaller cut blocks, or a combination of the two could be implemented for an estimated cost increase on the wood actually removed of 27 to 82 cents per cunit, between 1 to $3 \%$ of the estimated total cost per cunit of wood at the mills. These estimates suggest that a considerable variety of logging methods could be combined into an integrated approach to land management without prohibitive increases in cost. Through planned manipulation of timber stocks, it is possible in some regions to produce a more balanced wild ungulate habitat that "ould involve minimal expense and ensure the welfare of all forest animals.

If the production of higher numbers of wild ungulates is a desirable objective of land managers, research findings on the habitat requirements of wild ungulates and their relationships to forestry practice should be incorporated more quickly into the decision-making process. Foresters should apply alreadyknown forestry and wildlife management principles towards improvement of wild ungulate habitat. As Poole (1974) stated "If forestry is good for wildlife, then why should elk and other browsers wait for an 80- to 100-year timber rotation when forage is needed now? If multiple use is an arguable public land management objective, then why should wildlife, which have a much shorter rotation, wait for trees? Aren't all values to receive consideration under a balanced land management program?"

\section{Management and Improvement of Range for Domestic Live- stock}

The management and improvement of rangelands for livestock offer major opportunities for modifying existing practices to benefit wild ungulates. In the past, most range

\footnotetext{
A unite of stacked wood containing $2.83 \mathrm{~m}^{3}\left(100 \mathrm{ft}^{3}\right)$ of solid volume.
}

improvement plans have given priority to only one or two species of domestic or wild grazing animals. However, evaluations of the effects of such improvements on other species are required.

Millions of hectares of sagebrush and pinyon-juniper in western U.S.A. have been plowed, burned, chained, or sprayed to allow increased growth of grasses. The value of such treatments in terms of increased forage production for livestock is generally not questioned, but their impacts on wild ungulate winter range may be quite inimical. Sites supporting abundant browse for wild ungulates and areas inaccessible to livestock should be excluded from such treatments on public lands. It has been suggested that when pinyon-juniper stands in New Mexico are cleared and seeded to grasses for livestock range improvement, slopes steeper than $15 \%$ and some northern exposures should be left intact to provide cover and refuge for deer and elk (Reynolds 1964); added advantages from excluding such areas should include erosion control and increased cost effectiveness. Lamb (1966) concluded from revegetation experiments on overused mountain meadows, pinyon-juniper ranges, and sagebrush stands in New Mexico that ". . . if the range improvement for domestic stock is confined to the areas on which it is most economical to do this work, the rougher areas that are less desirable for domestic stock can be left for game and both the game and domestic livestock will be benefitted." Except where shrubs were totally eradicated and cover eliminated, Gibbens and Schultz (1963) reported that resident deer herds increased rapidly in foothill areas of California where ranchers made large-scale attempts to improve shrub ranges for livestock by controlled burning and by burning in combination with mechanical and chemical treatments.

Herbicide applications on livestock ranges can also improve conditions for wild ungulates. However, treatment of large tracts of land can be detrimental to wild ungulates by reducing cover and desirable forage species.

Based on a study of the effects of sagebrush manipulation to improve livestock forage on an important deer winter range in central Oregon, Urness (1967) concluded: "Deer distribution would likely be improved by scattered blocks or patterned treatments of moderate size, whether by seeding, roto-beating or spraying. Diversity of cover types over relatively short distances is the key. Greater attractiveness of borders between cover types is almost axiomatic to game management. . . Crested wheat-grass seedings contribute significantly to deer winter diets by providing nutritious herbaceous forage presently in short supply. Seed blocks, interspersed throughout untreated sagebrush stands, appear to enhance sagebrush values." Thus, conversion of the entire brushlands to grasslands is sub-optimal for wildlife. Antelope, for instance, can suffer reduction in numbers if their winter range is converted to grasslands (Brown 1967). Mitchell and Smoliak (1971) reported that management procedures for antelope in Alberta must be based on recognition of silver sagebrush (Artemisia cana) and pasture sagewort ( $A$. frigida) as the key foods for these animals. Management procedures on the ranges of these antelope may, therefore, preclude herbicide applications which would reduce those shrubs.

Hungerford (1970) reported on the effects of seeding, logging, fire, and other types of treatment on summer range of mule deer on the Kaibab Plateau, Arizona. The recent natural and man-caused changes, such as seeding, logging, fire, and range treatments, were largely beneficial and resulted in increased quantity and variety of summer food, improved 
animal condition, and increased rate of reproduction. Through use of forage in the created openings, mule deer also appeared to establish new home ranges.

Increasing the amount of palatable forage for livestock, thereby reducing their impact on browse, can be beneficial to browsing wild ungulates; for example, when the browse removed to seed grass is less valuable than that which would be saved for wild ungulates by reduction of livestock competition. Although areas seeded to grass receive some use by wild ungulates, especially in the spring, more use would be made of these areas if they were more attractive through inclusion of legumes, others forbs, and browse in the mixture. This would require improvement of wild ungulate habitat to be an explicit goal of the treatment.

Another improvement practice, water development, is an obvious and often-used tool for obtaining better livestock distribution on a range. Such development, when properly planned, often benefits wild ungulates either directly or indirectly.

\section{Summary and Perspectives}

More range-improvement and timber-management practices should be implemented with a multiple-use concept in mind. Multiple use need not mean that a range must always be shared by cattle and wild ungulates; rather, there may be provisions within an area for foraging by only cattle or only wild ungulates. On public land, because of the relatively high unit costs for many improvements, projects may be more economically justified when multiple benefits accrue.

To ensure that game habitat values are coordinated with other uses, the game manager must maintain close contact with other resource administrators. Land-use planning on a local, statewide or provincial basis, or on a national scale should recognize wild ungulate ranges as important entities and should restrict less appropriate and conflicting land-use practices.

\section{Enhancement of Wild Ungulate Habitats}

It is desirable for agencies to continue to acquire and permanently to manage winter ranges of wild ungulates. This is particularly true because of the continued pressures of other land uses. However, much must be learned about the management of such areas. Sometimes goals may be clear, but methods adopted fail to achieve them. For example, livestock grazing was excluded after such lands were acquired in eastern Washington (Brown and Martinsen 1967). After 20 or more years of exclusive wild-ungulate use, vegetation transects were remeasured to determine the changes that had taken place. On each of the four wild-ungulate ranges examined-two used exclusively by deer and two used primarily by elk - the forb and browse species most preferred by the respective ungulates had declined and succession had progressed toward a climax bunchgrass vegetation type. Some of the ranges had changed to a point where they appeared to be best suited for cattle grazing. Thus, the long-term elimination of livestock grazing did not achicve the management goal of maintaining good wild ungulate ranges in continuous production. If the amount and type of forage and time of grazing are properly allocated, use of wild-ungulate winter ranges by domestic stock during other seasons of the year will balance grazing pressures and help prevent the vegetative changes caused when only one class of animal continually uses the range.

There are other examples where integration of wildlife use with other uses is appropriate. Livestock grazing has been used to improve markedly the quality of winter forage for elk in the
Bridge Creek Wildlife Management Area in northeast Oregon (Anderson and Scherzinger 1975). Gibbens and Schultz (1962) suggested that cattle be used to provide flexibility and control of browsing and grazing pressure on a deer winter range in California. On a winter-spring, wild-ungulate range in southeastern British Columbia, Hudson et al. (1976) found that distributions of white-tailed deer (Odocoileus virginianus), mule deer, elk, and bighorn sheep were influenced only mildly by summer cattle grazing at the rate of 350-500 animal unit months in an area of $51.8 \mathrm{~km}^{2}$ (20 square miles).

Important animal-vegetation interactions have been recorded on foothill ranges in the Intermountain area, where ranges have been grazed by livestock during the spring and fall and by browsing wild ungulates during the winter. Use by wild ungulates alone caused herbaceous vegetation increases at the expense of browse species. Heavy livestock use produced the opposite result (Smith 1949). Both livestock and wild ungulate pressures may be necessary for balanced use of browse and herbaceous forages to maintain plant communities productive for each kind of animal-a desirable objective under multiple use.

A few data are available for use as guides in managing these ranges for optimum forage and animal production. In Utah, cattle were studied to determine the period and intensity of summer grazing that would reduce competition of herbaceous vegetation with bitterbrush plants on wild ungulate winter range. Smith and Doell (1968) reported that mixed browseherbaceous ranges used by wild ungulates during the winter should be grazed by cattle only up to July 1 if use of bitterbrush is to be held to a minimum.

Another study carried out in the same area determined the dietary competition between wild ungulates and sheep (Jensen et al. 1972). Use of shrubs by sheep during late spring and early summer resulted in little or no reduction in shrub production at the end of the growing scason. Heavy utilization of bitterbrush by sheep occurred after mid-July, but sheep grazing prior to mid-July held forage competition with wild ungulates to an acceptable level. The results of both studies (Smith and Doell 1968; Jensen et al. 1972) suggested that reducing competition for moisture and nutrients by allowing domestic livestock to remove grass and forbs early in the grazing season can stimulate the growth of browse. In addition, Fulgham (pers. comm.) found that the spring-time sheep grazing in that area increased crude protein content and in vitro digestibility of subsequent late winter diets consumed by mule deer.

Skovlin et al. (1968) studied the influence of deferredrotation range use, season-long range use, and cattle stocking rates on deer and elk on ponderosa pine-bunchgrass summer range in the central Blue Mountains of northeastern Oregon. Elk use decreased as cattle stocking rates increased, but deer use was little influenced by the rate of cattle stocking. As the rate of stocking increased, however, deer tended to use grasslands to a greater extent. Elk preferred ranges used all season long at a light cattle stocking rate and ranges under a deferred-rotation system at a heavy cattle stocking rate. Deer preferred deferred-rotation ranges to ranges used season-long. The authors concluded that cattle stocking at a rate between light and moderate would result in good overall production on dual-use ranges.

Dual use has been reported to be efficient in other regions also. For example, observation of summer and winter food habits of mule deer and cattle in a prairie habitat of north-central Montana indicated no significant forage competition (Dusek 
1975). Thilenius and Hungerford (1967) also suggested that dual use of range by white-tailed deer and cattle in northern Idaho was efficient, provided that the forage species heavily used by one class of animal were not heavily used by the other.

When both the domestic and wild ungulates are grazers, animal-vegetation relationships may be more complex because of competition for the same plant species. For example, Demarchi (1973) studied the relationship of range quality to range condition in the Chilcotin region of British Columbia, which was used by livestock and California bighorn sheep. He found that the protein content of individual bluebunch wheatgrass (Agropyron spicatum) plants subjected to heavy winter and early spring grazing increased over that of nongrazed plants-although the total amount of protein per unit area declined. Due to uncontrolled livestock grazing, the dominant grass species on this range changed from the preferred bluebunch wheatgrass to the less desirable needle and thread (Stipa comata); Demarchi concluded that such livestock grazing was detrimental to bighorn sheep. Anderson and Scherzinger (1975) found that because of the increase in protein content (due to controlled spring grazing) in bluebunch wheatgrass and Idaho fescue (Festuca idahoensis) over that of climax condition bunchgrasses, these spring-grazed plants can be used as improved forage for wintering elk. Similarly, Hebert (1973) suggested that protein concentration, rather than total amount per unit area, has greater influence on the nutrition of bighorn sheep.

To manage properly such areas, we must know the use-tolerance of important forage species and the frequency with which this tolerance level can be reached without loss of plant vigor and productivity. Evidence suggests that moderate use may be essential for maintaining maximum production and for balancing animal pressures on range plants. In California, relatively heavy browsing by deer maintains some browse species in a usable, palatable, and nutritious form (Gibbens and Schultz 1963). Garrison (1953), Shepherd (1971), and Willard and McKell (1978) showed that production can actually be increased by some clipping treatments of certain shrubs. In the case of winter clipping of bitterbrush growing under favorable soil-moisture conditions, the greatest production was obtained with $75 \%$ of the current growth clipped; on drier sites, $50 \%$ twig removal was suggested to maintain the best production (Garrison 1953). More information of this type will be required for the long-term maintenance of permanent browse ranges.

The influence of diseases, insects, and other pests on wild ungulate habitat has received little attention (Furniss and Krebill 1972); more knowledge may aid us in the better management of wild ungulate habitats. The impact of the Aroga moth (Aroga websteri) on big sagebrush (Hall 1963, 1965) created concern, as did epidemics of tent caterpillars (Malacosoma fragilia) and other insects. Loss . of curl-leaf mountainmahogany to insects has been reported in Idaho (Furniss and Barr 1967). Leege and Furniss (1970) suggested that the poplar-and-willow borer (Sternochetus lapathi) may be competing with wild ungulates for browse in the brush fields of northern Idaho.

Few data are available on the effects of diseases on browse plants. Losses of browse now attributed to overuse by domestic animals and wild ungulates may actually be caused by insects or disease. However, overbrowsing can cause shrubs to lose vigor, which may in some cases encourage insects and diseases. Knowledge of insects and disease control is necessary for effective maintenance or improvement of browse production for wild ungulates. However, concerns about insects and diseases are easily overemphasized. Although outbreaks can be briefly spectacular, insects and diseases can usually be expected to recede by themselves because they evolved together with the shrubs in most cases and, despite occasional oscillations, have developed dynamic equilibria.

The possible effects of rodents and lagomorphs on habitat are also poorly known, although specific kinds of damage are welldescribed. Small rodents caused girdling damage to a large portion of the big sagebrush plants on an experimental winter range in northern Utah. Had it not been for ongoing studies, it is probable that shrub mortality would have been attributed to use by deer and elk (D. Doell, pers. comm.). Small rodents also killed and damaged big sagebrush and other shrub species in Montana (Mueggler 1967); Idaho (Phillips 1970); and Utah and Nevada (Frischknecht and Baker 1972). There apparently is little information on the extent and frequency of such rodent damage. Nor is there sufficient information about the natural rate of reestablishment of sagebrush, or the carrying capacity of plants that might replace it, following damage by rodents.

In contrast, deer mice (Peromyscus maniculatus) and pinyon mice $(P$. truei) were believed to be more beneficial than detrimental to a pinyon-juniper (Pinus edulis-Juniperus utahensis) deer range because they consumed large quantities of insects (Shepherd 1972).

From personal observations made in Utah, I believe that jackrabbits (Lepus californicus) can influence the success of certain plants in revegetation projects. Some legumes and other plants, such as yellow sweet clover (Melilotus officinalis), alfalfa (Medicago sativa), cicer milkvetch (Astragalus cicer), sicklepod milkvetch (A. falcatus), and small burnet (Sanguisorba minor), were so palatable to jackrabbits that those young plants were nearly eliminated before the seeded pastures were well established.

In summary, guidelines for allocation of forage to livestock and wildlife on wild ungulate winter ranges should be developed by land managers. Such guidelines should enable managers who have such goals to maintain productive wild ungulate habitat on primarily livestock range. Introduction of livestock grazing in publicly owned wild ungulate habitat would better justify its maintenance by increasing economic arguments against inimical, competitive, or irreversible uses. Available evidence supports the generalization that dual use by livestock and wild ungulates, when properly planned, can benefit both classes of animals; however, careful monitoring of the effects of implementing these management practices is required to maintain the correct balance of usage rates and timing, to take advantage of the complementary relationship between the two groups. We should also recognize that wild ungulate use of private lands without economic compensation to the owners helps to justify grazing of livestock on public lands, as does the need for meat and hides from livestock.

\section{Manipulation of Animal Numbers and Distribution}

Particular habitats can sometimes be improved and maintained through skillfull management of animal harvests. Game managers can often manipulate animal numbers more effectively through properly planned harvests than through manipulation of environmental factors to improve habitat. Consequently, they should generally be more concerned with preventing habitat deterioration than with the risk of over-liberal harvests. Over-harvesting usually can be corrected by subsequent more conservative regulations, but habitat deterioration may be either irreversible or reversible only after expensive treatments or over 


\section{a long period of time.}

In certain areas, the available supply of forage far exceeds the requirements of existing wild ungulate herds. In these cases, redistributing animals may be more effective than manipulating numbers or habitats. Salting, fertilizer applications, and water developments encourage use of those areas; by application of such techniques the grazing pressure on overused portions of ranges could be reduced allowing recovery.

Certain techniques of influencing animal distribution have met with only limited or qualified success. Salt successfully influenced elk movements in Idaho and Montana (Case 1938; Cooney 1951; Dalke et al. 1965), but adverse effects of salting in other areas included the spread of contagious ecthyma and disruption of seasonal movements of bighorn sheep and mountain goats (Blood 1971; Samuel et al. 1975).

Fertilizer has been applied to rangelands both to improve the quantity and quality of forage and to influence wild ungulate distribution. As a management technique, commercial fertilizer has been applied to state operated hayfields in Washington to make that attractive to elk and thereby reduce damage to adjacent private hayfields (Brown and Mandery 1962). However, when ranchers in the area used fertilizer to improve yields on their hayfields, the elk moved back. In eastern Oregon, fertilization of timothy (Phleum pratense) markedly increased elk use (Geist et al. 1974). Gibbens and Pieper (1962) studied the response of two browse plants to fertilizer on a deer winter range in California. They reported fertilizers generally increased growth and palatability of the shrubs and caused selective thinning and browsing. In Washington, Pierson et al. (1967) indicated an increase in browse production and use by elk due to fertilizer application. Another valuable application of this technique was reduction of deer damage to fir seedlings on fertilized areas, where increased browse growth and utilization were reported by Rieck and Jeffrey (1964). Basile (1970) reported that in Montana, fertilizer applications on lowproducing sites used by elk as winter range can be a valuable restorative measure when used in conjunction with a sound herd-management program.

Bayoumi and Smith (1976) reported the responsc of vegetation on winter range of big game in northern Utah to nitrogen and phosphorus fertilizer. Nitrogen-fertilized bitterbrush and sagebrush plants produced greater yields and were used more heavily by elk than were unfertilized plots; phosphorus applications increased neither yield nor use. The use of fertilizer and herbicides in combination can also benefit game ranges by stimulating plant growth and by making plants more palatable to wild ungulates (Carpenter and Williams 1972); such combined treatment can also influence wild ungulate distribution.

Availability to water is, for obvious reasons, an important limiting factor for wild ungulate populations in parts of the arid West (Weaver et al. 1959). Water is considered an essential part of successful desert bighorn sheep management in southwestern United States (Stanton 1951; Halloran and Deming 1956). Experimental water developments are being used in Nevada and southeastern Utah in an attempt to spread the distribution of desert bighorn sheep. Water development, particularly during dry seasons or drought years, can encourage better distribution of antelope (Beale and Scotter 1968; Beale and Smith 1970).

\section{Research Needs in Habitat Management}

The most persistent need in the field of wild ungulate management is for knowledge of the amount and kinds of habitat needed to maintain wild ungulate populations, especially in the context of multiple-use management where forestry, recreation, water, and other values are to receive full consideration. In most, if not all, regions of North America, research in habitat management is far behind the needs of resource administrators. In particular, a better understanding of habitat requirements in relation to wild ungulate behavior is imperative to wise management decisions.

Because effects of land-use and habitat-improvement practices are complex and long-range, administrators must be encouraged to support long-term research directed at solving specific management problems, provided it has clearly defined goals and interim points at which progress can be measured. Also, investigators must fulfill the obligation to publish their results. Efforts during the preparation of this paper uncovered large amounts of research data which was unavailable in published form.

Many managers and some researchers tend to equate production of forage with habitat. One result is a general failure to recognize the importance of aspects other than forage. Determinants of habitat use by wild ungulates require better definition. For example, what is the relative importance of forage-related compared with structure-related habitat features as predictors of habitat use? An understanding of the optimal juxtaposition of usable forage with other habitat requirements is urgently needed. Managers also need to find ways of ensuring that a created forage resource will be used. For example, there is considerable effort in several western States to determine the extent and cause of some undesirable behavioral patterns of clk in response to logging. Activities and noise associated with logging and vehicular traffic on forest roads disturb elk and can cause them to move a considerable distance (Lyon 1975). If elk leave an area, a new forage resource (as might be created by the logging) is of little value. In reference to clearcuts in Montana, Lyon (1976) suggested that ". . . the size of the opening, vehicle access and available cover are keys to secure use of the forage by elk, but the relative importance of different kinds of security will vary for each situation."

Effects of human encroachment upon rangelands also should be studied from the standpoint of animal behavior. The security of habitats can greatly influence their use. A disturbance that prevents wild ungulates from using preferred components of the habitat may result in reduced physical condition and lower reproductive rates. Thus research should be concerned not only with the quality and quantity of habitat but also with whether habitat can and will be used; otherwise, it is possible that much habitat will be underutilized or completely sterile in terms of wild ungulate production.

If the game management profession is to manage wild ungulates and their habitats in order to produce sustained annual crops of wild ungulates for human benefits, it is vital that this group ambitiously address the challenges inherent in the types of research necessary to find ways of ensuring such production, and in the application of that knowledge.

\section{Literature Cited}

Anderson, E.W., and R.J. Scherzinger. 1975. Improving quality of winter forage for elk by cattle grazing. J. Range Manage. 28:120-125.

Baker, F.S. 1925. Aspen in the Central Rocky Mountain Region. U.S. Dep. Agr. Bull. 1291. 43 p.

Basile, J.V. 1970. Fertilizing to improve elk winter range in Montana. U.S. Dep. Agr., Forest Serv., Intermountain Forest Range Exp. Sta., Res. Note INT-113. $6 \mathrm{p}$. 
Basile, J.V., and C.E. Jensen. 1971. Grazing potential on lodgepole pine clearcuts in Montana. U.S. Dep. Agr., Forest Serv., Intermountain Forest Range Exp. Sta., Res. Pap. INT-98. 11 p.

Bayoumi, M.A., and A.D. Smith. 1976. Response of big game winter range vegetation to fertilization. J. Range Manage. 29:44-48.

Beale, D.M., and G.W. Scotter. 1968. Seasonal forage use by pronghorn antelope in western Utah Sci. 29:3-6 and 16.

Beale, D.M., and A.D. Smith. 1970. Forage use, water consumption, and productivity of pronghom antelope in western Utah. J. Wildl. Manage. 34:570-582.

Bergerud, A.T., and F. Manuel. 1968. Moose damage to balsam fir-white birch forest in central Newfoundland. J. Wildl. Manage. 32:729-746.

Biswell, H.H. 1961. Manipulation of chamise brush for deer range improvement. Calif. Fish Game 47:125-144.

Biswell, H.H., and J.H. Gilman. 1961. Brush management in relation to fire and other environmental factors on the Tehama deer winter range. Calif. Fish Game 47:357-389.

Biswell, H.H., R.D. Taber, D.W. Hedrick, and A.M. Schultz. 1952. Management of chamise brushlands for game in the north coast region of California. Calit. Fish Game 38:453-484.

Blood, D.A. 1966. Range relationships of elk and cattle in Riding Mountain National Park, Manitoba. Can. Wildl. Serv. Rep. Ser. 1, No. 19. 62 p.

Blood, D.A. 1971. Contagious ecthyma in Rocky Mountain bighorn sheep. J. Wildl. Manage. 35:270-275.

Borrecco, J.E., H.C. Black, and E.F. Hooven. 1972. Response of blacktailed deer to herbicide-induced habitat changes. Proc. Annu. Conf. West. Ass. State Game Fish Comm. 52:437-449.

Bowns, J.E., and N.E. West. 1976. Blackbrush (Coleognyne ramosissima Torr.) on southwestern Utah rangelands. Utah Agr. Exp. Sta. Res. Rep. 27. $27 \mathrm{p}$.

Brown, E.R. 1961. The black-tailed deer of western Washington. Wash. Game Dep. Biol. Bull. 13. 124 p.

Brown, E.R. 1967. Impact of range improvement practices on wildlife. In: Symp. Proc. Herbicides and Veg. Manage., School of Forest., Oregon State Univ. p. 215-219.

Brown, E.R., and J.H. Mandery. 1962. Planting and fertilization as a possible means of controlling distribution of big game animals. J. Forest. 60:33-35.

Brown, E.R., and C.F. Martinsen. 1967. Vegetational changes on some eastern Washington winter game ranges. Paper presented at the 20th annual meeting, Amer. Soc. Range Manage., Seattle, Wash. 9 p.

Carpenter, L.H., and G.L. Williams. 1972. A literature review on the role of mineral fertilizers in big game range improvement. Colo. Div. Game Fish Parks, Spec. Rep. No. 28. 25p.

Case, G.W. 1938. The use of salt in controlling the distribution of game. J. Wildl. Manage. 2:79-81.

Cook, C.W., G.W. Scotter, J.B. Low, G.F. Gifford, and J.D. Hunt. 1968. Benefits and concerns in the control of range weeds. Utah Weed Control Conf. p. 1-5.

Cooney, R.F. 1951. Salt as a management tool. Proc. Annu. Conf. West. Ass. State Game Fish Comm. 31:99-105.

Cowan, I.M., W.S. Hoar, and J. Hatter. 1950. The effect of forest succession upon the quantity and upon the nutritive values of woody plants used as food by moose. Can. J. Res. 28(D):249-271.

Dalke, P.D., R.D. Beeman, F.J. Kindel, R.J. Robel, and T.R. Williams. 1965. Use of salt by elk in Idaho. J. Wildl. Manage. 29:319-332.

Demarchi, D.A. 1973. Relationship of range quality to range conditions in the Chilcotin Region, British Columbia. J. Range Manage. 26:345-348.

Diem, K.I. 1963. An evaluation of chemical and mechanical rehabilitation of decadent mountain mahogany (Cercocarpus montanus). Proc. Annu. Conf. West. Ass. State Game Fish Comm. 43:123-128.

Dodds, D.G. 1960. Food competition range relationship of moose and snowshoe hare in Newfoundland. J. Wildl. Manage. 24:52-60.

Dost, F.M. 1973. 2,4,5-T, a case history of evaluation of a possible public hazard. In: The use of herbicides in vegetation management, final environmental statement, U.S. Dep. Agr. Forest Serv. 6 p.

Dusek, G.L. 1975. Range relations of mule deer and cattle in prairie habitat. J. Wildl. Manage. 39:605-615.

Eastman, D. 1978. Prescribed burning for wildlife habitat management in British Columbia. In: D.E. Dube (ed.) Fire ecology in resource management. Can. Forest Serv. Inform. Rep. NOR-X-210. p. 103-111.

Edgerton, P.J. 1972. Big game use and habitat changes in a recently logged mixed conifer forest in northeastern Oregon. Proc. Annu. Conf. West. Ass. State Game Fish Comm. 52:239-246.

Edwards, R.Y. 1954. Fire and the decline of a mountain caribou herd. J. Wildl. Manage. 18:521-526.

Ferguson, R.B. 1972. Bitterbrush topping: shrub response and cost factors.
U.S. Dep. Agr. Forest Serv., Intermountain Forest Range Exp. Sta., Res. Pap. INT-125. 11p.

Ferguson, R.B., and J.V. Basile. 1966. Topping stimulates bitterbrush twig growth. J. Wildl. Manage. 30:839-841.

Forest-Range Task Force. 1972. The nation's range resources, a forestrange environmental study. U.S. Dep. Agr. Forest Serv., Forest Resource Rep. No. 19. 147 p.

Forest Service. 1972. Fire in the environment symposium proceedings. U.S. Dep. Agr. FS-276. $151 \mathrm{p}$.

Frischknecht, N.C., and M.F. Baker. 1972. Voles can improve sagebrush rangelands. J. Range Manage. 25:466-468.

Furniss, M.M., and W.F. Barr. 1967. Bionomics of Anacamptodes clivinaria profanata (Lepidoptera: Geometridae) on Mountain Mahogany in Idaho. Univ. Ida. Agr. Exp. Sta., Res. Bull. 73. 24 p.

Furniss, M.M., and R.G. Krebill. 1972. Insects and disease of shrubs on western big games ranges. In: C.M. McKell, J.P. Blaisdell and J.R. Goodin (Eds.) Wildland shrubs-their biology and utilization. U.S. Dep. Agr. Forest Serv., Intermountain Forest Range Exp. Sta. Gen. Tech. Rep. INT-1. p. $218-226$.

Garrison, G.A. 1953. Effects of clipping on some range shrubs. J. Range Manage. 6:309-317.

Gates, B.R. 1968. Deer food production in certain seral stages of the Coast Forest. Unpub. M.S. Thesis, Univ. British Columbia, Vancouver. 105 p.

Geist, J.M., P.J. Edgerton, and G.S. Strickler. 1974. 'Yukky to yummy'with fertilizers. Rangeman's J. 1:39-41.

Gibbens, R.P., and R.D. Pieper. 1962. The response of browse plants to fertilization. Calif. Fish Game 48:268-281.

Gibbens, R.P., and A.M. Schultz. 1962. Manipulation of shrub form and browse production in game range improvement. Calif. Fish Game 48:49-64.

Gibbens, R.P., and A.M. Schultz. 1963. Brush manipulation on a deer winter range. Calif. Fish Game 49:95-118.

Gordon, F.A. 1976. Spring burning in an aspen-conifer stand for maintenance of moose habitat, West Boulder River, Montana. Proc. Annu. Tall Timbers Fire Ecol. Conf. 14:501-538.

Hall, R.C. 1963. Impact on antelope and deer sagebrush ranges by the sagebrush defoliator-Aroga websteri. Trans. Interstate Antelope Conf. 14:40-48

Hall, R.C. 1965. Sagebrush defoliator outbreak in northern California. U.S. Dep. Agr. Forest Serv., Res. Note PSW-75. 12 p.

Halloran, A.F., and O.V. Deming. 1956. Water development for desert bighorn sheep. U.S. Fish Wildl. Serv., Wildl. Manage. Ser. Leaflet No. 14. $12 \mathrm{p}$.

Hanks, D.L., E.D. McArthur, R. Stevens, and A.P. Plummer. 1973. Chromatographic characteristics and phylogenetic relationships of Artemisia section Tridentatae. U.S. Dep. Agr., Forest Serv., Res. Pap. INT-141. 24 p.

Hanks, D.L., E.D. McArthur, A.P. Plummer, B.C. Giunta, and A.C. Blauer. 1975. Chromatographic recognition of some palatable and unpalatable subspecies of rubber rabbitbrush in and around Utah. J. Range Manage. 28:144-148.

Hebert, D.M. 1973. Altitudinal migration as a factor in the nutrition of bighorn sheep. Unpub. Ph.D. Thesis, Univ. British Columbia, Vancouver. $357 \mathrm{p}$.

Hoffer, M.C. 1972. Lemmon ceanothus-chamise mule deer range improvement with 2,4-D. Proc. Annu. Conf. West. Ass. State Game Fish Comm. 52:467-481.

Holmgren, R.C., and J.V. Basile. 1959. Improving southern Idaho deer winter ranges by artificial revegetation. State Ida. Dep. Fish Game, Wildl. Bull. 3. 61 p.

Hubbard, R.L. 1962. The place of browse seeding in game range management. N. Amer. Wildl. Natur. Res. Conf. 27:394-401.

Hubbard, R.L. 1964. A guide to bitterbrush seedings to California. U.S. Dep. Agr. Forest Serv., Pacific Southwest Forest and Range Exp. Sta. 30 p.

Hudson, R.J., D.M. Hebert, and V.C. Brink. 1976. Occupational patterns of wildlife on a major east Kootenay winter-spring range. J. Range Manage. 29:38-43.

Hungerford, C.R. 1970. Response of Kaibab mule deer to management of summer range. J. Wildl. Manage. 34:852-862.

Idstrom, J.M. 1965. The moose in Minnesota. In: J.B. Moyle (Ed.) Big game in Minnesota. Minn. Dep. Conserv., Div. Fish Game, Tech. Bull. No. 9. p. 57-98.

Intermountain Fire Research Council. 1970. The role of fire in the Intermountain West. School Forest, Univ. Mont., Missoula. 229 p.

Jensen, C.H., A.D. Smith, and G.W. Scotter. 1972. Guidelines for grazing sheep on rangelands used by big game in winter. J. Range Manage. 25:346352.

Jones, J.R. 1975. Regeneration on an aspen clearcut in Arizona. U.S. Dep. Agr. Forest Serv. Rocky Mountain Forest Range Exp. Sta., Res. Note 


\section{RM-285. 8 p.}

Kufeld, R.C. 1977. Improving Gambell oak ranges for elk and mule deer by spraying with 2,4;5-TP. J. Range Manage. 30:53-57.

Lamb, S.H. 1966. Game range revegetation in New Mexico. Proc. Annu. Conf. West. Ass. State Game Fish Comm. 46:194-202.

Lauer, J.L., and J.M. Peek. 1976. Big game-livestock relationships on the bighorn sheep winter range East Fork Salmon River Idaho. College Forest., Wildl. Range Sci., Univ. Idaho, Bull. No. 12. 44 p.

Leege, T.A. 1968. Prescribed burning for elk in northern Idaho. Proc. Annu. Tall Timbers Fire Ecol. Conf. 8:235-253.

Leege, T.A. 1969. Burning seral ranges for big game in northern Idaho. N. Amer. WildI. Natur. Res. Conf. 34:429-438.

Leege, T.A., and M.M. Furniss. 1970. A pint-sized browser, the willow borer. Idaho Wildl. Rev. 23:12-14.

Leege, T.A., and W.O. Hickey. 1971. Sprouting of northern Idaho shrubs after prescribed burning. J. Wildl. Manage. 35:508-515.

Leopold, A. 1933. Game Management. Charles Scribner's Sons, New York. $481 \mathrm{p}$.

LeResche, R.E., R.H. Bishop, and J.W. Coady. 1974. Distribution and habitats of moose in Alaska. Naturaliste Can. 101:143-178.

Loope, L.L., and G.E. Gruell. 1973. The ecological role of fire in the Jackson Hole area, northwestern Wyoming. J. Quat. Res. 3:425-443.

Lyon, L.J. 1966a. Problems of habitat management for deer and elk in the northern forests. U.S. Dep. Agr., Forest Serv., Intermountain Forest Range Exp. Sta., Res. Pap. INT-24. 15 p.

Lyon, L.J. 1966b. Initial vegetal development following prescribed burning on Douglas-fir in south-central Idaho. U.S. Dep. Agr., Forest Serv., Intermountain Forest Range Exp. Sta., Res. Pap. INT-29. 17 p.

Lyon, L.J. 1971. Vegetal development following prescribed burning of Douglas-fir in south-central Idaho. U.S. Dep. Agr., Forest Serv., Intermountain Forest Range Exp. Sta., Res. Pap. INT-105. 30 p.

Lyon, L.J. 1975. Coordinating forestry and elk management in Montana: initial recommendations. N. Amer. Wildl. Natur. Res. Conf. 40:193-201.

Lyon, L.J. 1976. Elk use of disturbed areas. Montana cooperative elklogging study. Annu. Prog. Rep. p. 67-77.

Lyon, L.J., and W.F. Mueggler. 1968. Herbicide treatment of north Idaho browse evaluated six years later. J. Wildl. Manage. 32:538-541.

Markgren, G. 1974. The moose in Fennoscandia. Naturaliste Can. 101:185194.

Martinka, C.J. 1976. Fire and elk in Glacier National Park. Proc. Annu. Tall Timbers Fire Ecol. Conf. 14:377-389.

McArthur, E.D., B.C. Giunta, and A.P. Plummer. 1974. Shrubs for restoration of depleted ranges and disturbed areas. Utah Sci. 35:28-33.

McKell, C.M., J.P. Blaisdell, and J.R. Goodin (Eds.). 1972. Wildland shrubs-their biology and utilization. U.S. Dep. Agr., Forest Serv., Intermountain Forest Range Exp. Sta., Gen. Tech. Rep. INT-1 494 p.

Medin, D.E., and R.B. Ferguson. 1972. Shrub establishment on game ranges in the northwestern United States. In: C.M. McKell, J.P. Blaisdell and J.R. Goodin (Eds.) Wildland shrubs-their biology and utilization. U.S. Dep. Agr., Forest Serv., Intermountain Forest Range Exp. Sta., Gen. Tech. Rep. INT-1. p. 359-368.

Minnich, D.W. 1969. Vegetative response and pattern for deer use following chaining of pinyon and juniper forest. Pap. presented 22nd Annu. Meeting, Amer. Soc. Range Manage. Calgary, Alta. 13 p.

Mitchell, G.J., and S. Smoliak. 1971. Pronghorn antelope range characteristics and food habits in Alberta. J. Wildl. Manage. 35:238-250.

Mueggler, W.F. 1966. Herbicide treatment of browse on a big game winter range in northern Idaho. J. Wildl. Manage. 30:141-151.

Mueggler, W.F. 1967. Voles damage big sagebrush in southwestern Montana. J. Range Manage. 20:88-90.

Nord, E.C. 1965. Autecology of bitterbrush in California. Ecol. Monogr. 35:307-334.

Outdoor Recreation Resources Review Commission. 1962. Outdoor recreation for America. Gov. Print. Off. Wash. 246 p.

Pase, $P$. 1958. Herbage production and compositon under immature ponderosa pine stands in the Black Hills. J. Range Manage. 11:238-248.

Patton, D.R. 1974. Patch cutting increases deer and elk use of a pine forest in Arizona. J. Forest. 72:764-766.

Pengelly, W.L. 1963. Timberlands and deer in the northern Rockies. J. Forest. 61:734-740.

Pengelly, W.L. 1966. Ecological effects of slash-disposal fires on the Coeur D'Alene National Forest, Idaho. Northern Region, U.S. Forest Serv., Missoula, Mont. $20 \mathrm{p}$.

Phillips, T.A. 1970. The status of antelope bitterbrush in the Cassia mountain area of southern Idaho. USDA, Forest Serv., Intermountain Region, Range Improvement Notes 15(4):1-15.

Pierson, D.J., J. Patterson, H.I. Brent, and C. Stoddard. 1967. Elk and forest succession. Job Compl. Rep., P.R. Proj. W69-R, Wash. Dep. Game. 6 p. (Multilith).

Pimlott, D.H. 1953. Newfoundland moose. N. Amer. Wildl. Conf. 18:563581.

Plummer, A.P. 1958. Restoration of juniper-pinyon ranges in Utah. Soc. Amer. Foresters Proc., Salt Lake City, Utah. p. 207-211

Plummer, A.P., D.R. Christensen, and S.B. Monsen. 1968. Restoring big game range in Utah. Utah Div. Fish Game Pub. No. 68-3. 183 p.

Plummer, A.P., S.B. Monsen, and D.R. Christensen. 1966. Fourwing slatbrush, a shrub for future game ranges. Utah Fish Game Dep. Pub. 66-4. 12 p.

Poole, D.A. 1974. The forester as seen by a wildlife professional. J. Forest. 72:483-485.

Prescott, W.H. 1968. A study of winter concentration areas and food habits of moose in Nova Scotia. Unpubl. M.Sc. Thesis, Acadia Univ., Wolfville, Nova Scotia. $194 \mathrm{p}$.

Reeher, J.A., Jr. 1969. Antelope use of rehabilitated sagebrush range in southeastern Oregon. Proc. Annu. West. Conf. Ass. State Fish Comm. 49:272277.

Regelin, W.L., O.C. Wallmo, J. Nagy, and D.R. Dietz. 1974. Effect of logging on forage values for deer in Colorado. J. Forest 72:282-285.

Reid, E.H. 1964. Forage production in ponderosa pine forests. Soc. Amer. Foresters Proc. p. 61-64.

Reynolds, H.G. 1962. Effect of logging on understory vegetation and deer use in a ponderosa pine forest of Arizona. U.S. Dep. Agr., Forest Serv., Rocky Mountain Forest Range Exp. Sta., Res. Note 80.7 p.

Reynolds, H.G. 1964. Elk and deer habitat use of a pinyon-juniper woodland in southern New Mexico. N. Amer. Wildl. Natur. Res. Conf. 29:438444.

Reynolds, H.G. 1966a. Slash cleanup in a ponderosa pine forest affects use by deer and cattle. U.S. Dep. Agr., Forest Serv., Rocky Mountain Forest Range Exp. Sta., Res. Note RM-64. 3 p.

Reynolds, H.G. 1966b. Use of openings in spruce-fire forests of Arizona by elk, deer, and cattle. U.S. Dep. Agr., Forest Serv., Rocky Mountain Forest Range Exp. Sta., Res. Note RM-66. 4 p.

Richards, T.H. 1957. Improving wildlife habitat. Proc. Annu. Conf. West. Ass. State Game Fish Comm. 37:73-77.

Rieck, C., and B. Jeffrey. 1964. Fertilization of deer browse. Wash. Dep. Game. 7 p. (Mimeo.).

Sampson, A.W. 1919. Effect of grazing upon aspen reproduction. U.S. Dep. Agr. Bull. 741.29 p.

Sampson, A.W. 1944. Plant succession on burned chaparral lands. Univ. Calif. Agr. Exp. Sta. Bull. 685. 144 p.

Samuel, W.M., G.A. Chalmers, J.G. Stelfox, A. Loewen, and J.J. Thomsen. 1975. Contagious ecthyma in bighorn sheep and mountain goat in western Canada. J. Wildl. Dis. 11:26-31

Scotter, G.W. 1971. Fire, vegetation, soil and barren-ground caribou relations in northern Canada. In: C.W. Slaughter, R.J. Barney, and G.M. Hanson (Eds.). Fire in the northern environment-a symposium. U.S. Dep. Agr., Pacific N.W. Forest Range Exp. Sta. p. 209-230.

Schultz, C.D. and Co. Ltd. 1973. The environmental effects of timber harvesting operations in the Edson and Grande Prairie forests of Alberta. Rep. for Minister of Lands and Forests, Edmonton, Alta. Vol. 1. 291 p. (Multilith).

Shapley, D. 1974. Herbicides: academy finds damage in Vietnam after a flight of its own. Science 183:1177-1180.

Shepherd, H.R. 1971. Effects of clipping on key browse species in southwestern Colorado. Colo. Div. Game, Fish Parks Tech. Pub. 28. 104 p.

Shepherd, H.R. 1972. Rodent effects on pinyon-juniper deer range. Colo. Div. Wildl. Final Job Rep. 70 p.

Skovlin, J.M., P.J. Edgerton, and R.W. Harris. 1968. The influence of cattle management on deer and elk. N. Amer. Wildl. Natur. Res. Conf. 33:169-181.

Simkin, D.W. 1965. A preliminary report of the woodland caribou study in Ontario. Ont. Dep. Lands Forests, Sec. Rep. (Wildl.) No. 59.76 p.

Slaughter, C.W., R.J. Barney, and G.M. Hansen. 1971. Fire in the northern environment-a symposium. U.S. Dep. Agr., Forest Serv., Pacific N.W Forest Range Exp. Sta. 275 p.

Smith, A.D. 1949. Effects of mule deer and livestock upon a foothill range in northern Utah. J. Wildl. Manage. 13:421-423.

Smith, A.D., and D.D. Doell. 1968. Guides to allocating forage between cattle and big game on big game winter ranges. Utah State Div. Fish Game Pub. 68-11. 32 p.

Smith, A.D., P.A. Lucas, C.O. Baker, and G.W. Scotter. 1972. The effects of deer and domestic livestock on aspen regeneration in Utah. Utah Div. Wildl. Res. Pub. No. 72-1. 32 p.

Spencer, D.L., and J.B. Hakala. 1964. Moose and fire in the Kenal. Proc. Third Annu. Tall Timbers Fire Ecol. Conf. p. 10-33. 
Springfield, H.W. 1970. Germination and establishment of fourwing saltbush in the southwest. U.S. Dep. Agr., Forest Serv., Rocky Mountain Forest Range Exp. Sta., Res. Pap. RM-55. 48 p.

Stanton, F.W. 1951. Water development as an aid to game distribution. Proc. Annu., West. Conf. Ass. State Game Fish Comm. 31:184-189.

Stelfox, J.G. 1975. Range ecology of Rocky Mountain bighorn sheep in Canadian national parks. Unpub. Ph.D. Thesis. Univ. Mont., Missoula. $234 \mathrm{p}$.

Stelfox, J.G., G.M. Lynch, and J.R. McGillis. 1976. Effects on clearcut logging on wild ungulates in the central Albertan foothills. Forest. Chron. 52:65-70.

Stelfox, J.G., and R.D. Taber. 1969. Big game in the northern Rocky Mountain coniferous forest. In: Center for National Resources (Ed.) Coniferous forests of the northern Rocky Mountains. Univ. Mont. Found., Missoula. p. 197-222.

Stevens, R., A.P. Plummer, C.E. Jensen, and B.C. Giunta. 1974. Site productivity classification for selected species on winter big game ranges of Utah. U.S. Dep. Agr., Forest Serv., Intermountain Forest Range Exp. Sta., Res. Pap. INT-158. 24 p.

Taber, R.D. 1956. Deer nutrition and population dynamics in the North Coast range of California. N. Amer. Wildl. Conf. 21:159-172.

Taber, R.D., and R.F. Dasmann. 1958. The black-tailed deer of the chapparral. Calif. Dep. Fish Game, Game Bull. 8. 163 p.

Telfer, E.S. 1970. Relationships between logging and big game in eastern Canada. Pulp Pap. Mag. Can. Oct. 2:3-7.

Telfer, E.S. 1974. Logging as a factor in wildlife ecology in the boreal forest. Forest. Chron. 50:186-190.

Terrel, T.L., and J.J. Spillett. 1975. Pinyon-juniper conversion: its impact

Statement of Ownership, Management, and Circulation

(Act of August 12, 1970), Sec. 3685, Title 39, United States Code)

1. Title of Publication: JOURNAL OF RANGE MANAGEMENT

2. Date of Filing: October 1, 1979

3. Frequency of Issue: Bimonthly

4. Location of Office of Publication: 2760 West Fifth Ave., Denver, Colo. 80204

5. Location of General Business Office: Same

6. Names and Address of:

Publisher: Society for Range Management, 2760 West Fifth Ave., Denver, Colo. 80204

Editor: Rex D. Pieper, Dept. of Animal and Range Sciences, New Mexico State Univ., Las Cruces, N. Mex. 88001

Managing Editor: Floyd E. Kinsinger, 2760 West Fifth Ave., Denver, Colo. 80204

7. Owner: Society for Range Management, 2760 West Fifth Ave.,

Denver, Colo. 80204

8. Known Bondholders, Mortgagees, etc.; None

9. For Completion by Nonprofit Organizations Authorized to Mail at Special Rates: The purpose, function, and nonprofit status of this organization and the exempt status for Federal income tax purposes have not changed during preceding 12 months.

10. Extent and Nature of Circulation

$\begin{array}{cc}\text { Avg.for } & \text { Actual for } \\ \text { issue nearest } \\ 12 \text { months } & \text { filing date }\end{array}$

$\begin{array}{lrr}\text { A. Total copies printed } & 6,711 & 6,675 \\ \begin{array}{lrr}\text { B. Paid Circulation } \\ \text { 1. Dealers, counter sales }\end{array} & 0 & 0 \\ \text { 2. Mail subscriptions } & 6,249 & 6,325 \\ \text { C. Total paid circulation } & 6,249 & 6,325 \\ \text { D. Free distribution } & 30 & 30 \\ \text { E. Total distribution } & 6,279 & 6,355 \\ \text { F. Copies not distributed } & 432 & 320 \\ \text { G. Total } & 6,711 & 6,675\end{array}$

I certify that the statements made by me above are correct and complete. -Floyd E. Kinsinger, Managing Editor. on mule deer and other wildlife. In: G.F. Gifford and F.E. Busby (Eds.) The pinyon-juniper ecosystem: a symposium. Utah Agr. Exp. Sta., Logan. p. 105-119.

Thilenius, J.F., and K.E. Hungerford. 1967. Browse usc by cattle and deer in northern Idaho. J. Wildl. Manage. 31:141-145.

Thompson, R.M. 1970. Experimental top pruning of Curl-Leaf Mahogany trees on the South Horn Mountain, Ferron Ranger District-MantiLaSal National Forest. U.S. Dep. Agr., Forest Serv., Intermountain Region, Range Improvement Notes 15(3):1-12.

Urness, P.J. 1967. Influence of range improvements on Artemisia deer winter range in central Oregon. Pap. presented 20th Annu. Meeting, Amer. Soc. Range Manage., Seattle, Wash. 12 p. (Mimeo.).

Vozeh, G.E., and H.G. Cumming. 1960. A moose population census and winter browse survey in Gogama District, Ontario. Unpub. rep. Ont. Lands Lands Forests. 31 p. (Typescript).

Wallmo, O.C., W.L. Regelin, and D.W. Reichert. 1972. Forage use by mule deer relative to logging in Colorado. J. Wildl. Manage. 36:1025-1033.

Weaver, R.A., F. Vernoy, and B. Craig. 1959. Game water development on the desert. Calif. Fish Game 45:333-342.

Wilbert, D.E. 1963. Some effects of chemical sagebrush control on elk distribution. J. Range Manage. 16:74-78.

Willard, E.E., and C.M. McKell. 1978. Response of shrubs to simulated browsing. J. Wildl. Manage. 42:514-519.

Wright, H.E., Jr., and M.L. Heinselman. 1973. The ecological role of fire in natural conifer forests of western and northern America. Quat. Res. 3:317-513.

Young, J.A., D.W. Hedrick, and R.F. Keniston. 1967. Forest cover and logging-herbage and browse production in the mixed coniferous forest of northeastern Oregon. J. Forest. 65:807-813.

\title{
Range Management Specialists for Overseas Technical Assistance Programs
}

\author{
Experienced in design-development/implementation- \\ evaluation.
}

Short and/or long-term consultant fee positions. Overseas experience and/or foreign language desired. Salaries open. Excellent benefits. Address responses to:
J. Fiester
Chemonics International Consulting Division
1120 19th Street NW, Suite 605
Washington, D.C. 20036 